原

\title{
横浜市におけるサルモネラ食中毒による社会的損失
}

\author{
山本茂貴 ${ }^{1)}$, 石渡正樹2) \\ 1)国立公衆衛生院, 衛生獣医学部 \\ 2)横浜市衛生局生活衛生部生活衛生課

\section{Cost-of-Illness by Foodborne Salmonellosis in Yokohama-city, Kanagawa, Japan.} \\ Shigeki YAMAMOTO') and Masaki ISHIWATA \\ ${ }^{1}$ Department of Veterinary Public Health, National Institute of Public Health, \\ Tokyo, Japan \\ ${ }^{2}$ Environmental Sanitation Division, Sanitation Deaprtment,Public Health Bureau, \\ Yokohama, Japan
}

(Recieved 1 Novenber 1998 / Accepted 30 November 1998)

\begin{abstract}
Summary
Influence of foodborne diseases to the society are revealed by the number of incidence, patients and death. It is difficult, however, to compare among these of the foodborne deseases. Those expressions also have the problem that it is difficult to evaluate the social and economic damage by the foodborne diseases.

To solve those problems, it is used that the infleuence of foodborne diseases to the society is revealed by the economic loss. It is difficult, however, for us to use the same method used in U.S.A. Therefore, we estimated the ecomonic loss by bacterial foodborne diseases by using data as possible as we can collect in Japan. Cost-of-Illness of Salmonellosis in Yokohama-city from 1991 to 1995 was 850 million yen (expressed by the value of yen in 1993). That was 170 million yen per year, and 44 thousand yen per patient, respectively. Total estimation of Cost-of-Illness of Salmonellosis in Yokohama -city was 77 million to 530 million yen. That was 23 thousand yen per patient.

To estimate these cost more precisely, however, we consider that it is necessary to continue further epidemiological study about foodborne illness.
\end{abstract}

\section{序 文}

平成 8 年は腸管出血性大腸菌 0157 にる集団食中毒 の続発，サルモネラによる食中毒の増加等近年になく食 中毒が社会的に問題となった年であり，食中毒事件数は 1,217 件，患者数は 43,954 人，死者数 15 人で，事件数，患 者数, 死者数ともこの 10 年で最も多い年となった ${ }^{1)}$ 。食中

連絡先： 7 108-8638 東京都港区白金台 4-6-1

Tel:03-3441-7111, Fax:03-3446-7162

e-mail:yamamoto@iph.go.jp
毒による被害はこれまで事件数，患者数，死者数という 直接的な被害を表す数值のみが，原因毎に集計されると いった手法で示めされてきた。しかし，このような指標 では 1 日で症状の治まった黄色ブドウ球菌による食中毒 の患者と腸管出血性大腸菌 O157による食中毒に感染し HUS をおこした患者も同じ 1 人という数字で計上され るために，単純にこの数字だけをもとにして行政が対策 の優先順位を考えることは困難である。また，ひとたび 食中毒が発生するとその被害は患者の発生という直接的 被害にとどまらず, 食中毒に伴う様々な間接的な被害が 生じている。小澤2は, 経済的被害を考える場合は人に对 
する直接的（一次的）被害の他に間接的被害を考慮する 必要があるとし, 1996年に O157が日本経済に与えた被害 を計算するための項目として，(1)家畜生産に及ぼした被 害，(2)消費の減少による損害，(3)価値の低下による損害， (4)調査・研究費, 会議費の支出, (5)輸出入の減少による 被害, (6)人の健康に及ぼす被害, (7)社会的損害, 8レジ ヤ一の損害を例示している。

行政が食中毒についての対策の優先順位や効率性を考 える場合に，このようないくつかの性質の違う被害の状 況を 1 つ単位にまとめて把握することが必要であり, 金額という単位であらわされた経済的損失額を知ること は重要と考える。

アメリカでは, 以前から食中毒の経済損失について研 究が行われており，1996年にはアメリカ農務省の Buzby ら ${ }^{3)}$ が, サルモネラ, カンピロバクター, 病原性大腸菌 O157：H7, リステリア菌, 黄色ブドウ球菌, ウェルシュ 菌の 6 種類の細菌による食中毒についてのこれまでの研 究をまとめて1993年の米ドルに換算した経済損失額の推 計額を発表している。

一方，日本ではこのような研究はほとんど行われてお らず，わずかに静岡県保健衛生部 ${ }^{4}$ が食中毒原因施設の うちの損害額が判明した施設の損害額の合計金額を，医 療費・見舞金・剭謝料, 休業にともなう損害, 食品廃棄 による損害, 雑費の 4 項目にわけて食中毒年報で発表し ている以外はほとんど行われていない。

そこで，本研究では細菌性食中毒による経済損失の推 計方法及び推計に必要なデー夕について米国, 特に Buzby らの方法と現在の日本で可能な方法を比較しな がら検討し, 横浜市におけるサルモネラ食中毒による食 中毒の損失額の推計を試みることにより，日本における 細菌性食中毒による経済損失額の推計に必要な要件につ いて考察した。

\section{方 法}

\section{1 日本の食中䓯の損害額推計法の検討}

Buzby ら ${ }^{3)}$ の推計方法は既存の疫学調査の積み重ねの 上に行われている。しかし，我が国おいては食中毒につ いての疫学調查は, 発生した食中毒の原因を究明し，そ の結果を事故の拡大と再発の防止に役立てることを目的 に行われ，まとめられたものがほとんどであり，Cohen らフの行った研究のように, 食中毒の損失について詳し く調査した研究はない。

食中毒の被害額を推計する方法として，1つの可能性 として考えられるのは，損害賠償保険金の額を調查する 方法である。食中毒の原因施設が日本食品衛生協会の行 う食中毒営業賠償共催に加入している場合に損害賠償金
が共済金として支払われる。この額について調査すると いう方法である。ただし，この方法は，共済に加入して いる施設のデータしか手に入れることしかできないため, 必ずしもすべてを把握することができない。

このようなことを考え合わせて，現在，入手可能なデ 一夕をもとに横浜市におけるサルモネラ食中毒の costof-illness の推計を行うこととした。

\section{2 cost-of-illness の推計の概要}

今回はこのサルモネラ食中毒の cost-of-illness につ いて, 横浜市の食中毒事件のデー夕をもとにした推計及 び，独自の方法で横浜市民全体を対象として発生を推定 したサルモネラ食中毒患者数をもとに行う推計の $2 つ の$ 方法による推計を試みた。食中毒事件のデー夕は現在入 手可能な最新の 5 年間（1991～1995年）を使用し，金額 は中央年である1993年の円で求めた。これに合わせるた めに横浜市民全体を対象として推定したサルモネラ食中 毒の推計も1993年のデータを用いた。

cost-of-illness の推計の手順は,

(1)患者数の把握

(2)受療パ夕ーンの推計

(3)患者 1 人あたりの医療費の推計

(4)患者 1 人あたりの間接費用の推計

(5)総費用 (cost-of-illness) の推計

の順番で行った，なお，この期間に横浜市内で発生した サルモネラによる食中毒事件で死者が出ていないこと， ここ数年のサルモネラ食中毒の死者数が全国で1〜3 名 ${ }^{199}$ と割合が少ないことから, 死者は発生しないものと 仮定して推計を行った。

\section{結 果}

\section{1 サルモネラ患者数の推計}

1.1 横浜市における食中毒事件のデー夕

今回用いたデー夕は，この報告の過程で横浜市衛生局 生活衛生部食品衛生課に集められたものを利用した。デ 一夕は事件毎に原因, 患者数, 重症 (入院) 者数, 患者 の年齢構成, 各症状を示した患者数, 原因究明のための 疫学調査などが記載されている。ただし，ここに記され たデータには医療機関の受診者の数（例外として入院患 者数のみ重傷者数として記載される。), 個々の患者の症 状は記載されていない。

以上のデータのうち入手可能であった最新のデータと して，1991～1995年の横浜市内におけるサルモネラによ る食中毒の, 事件数及び患者数(表 2 ), 年齢階級別患者 数（表 3 ）, 患者の症状の割合（表 4 ）を求めた。なお, 患者の症状の割合は, 症状の有無について確認できたも 
表 1 横浜市におけるサルモネラ食中毒事件数 及び患者数

\begin{tabular}{ccc}
\hline 年 & 事件数 (件) & 患者数 (大院者数) $($ 人) \\
\hline 1991 & 1 & $1(1)$ \\
1992 & 2 & $16(10)$ \\
1993 & 3 & $112(36)$ \\
1994 & 2 & $45(3)$ \\
1995 & 2 & $19(0)$ \\
\hline 合 $\quad$ 計 & 10 & $193(40)$ \\
\hline
\end{tabular}

表 2 1991〜 1995年に横浜市で起きた サルモネラ食中毒事件の患者の年齢構成

\begin{tabular}{crc}
\hline 年 齢 & 人 数 & 割 合(\%) \\
\hline $0 \sim 4$ & 2 & 1.0 \\
$5 \sim 9$ & 8 & 4.1 \\
$10 \sim 14$ & 18 & 9.3 \\
$15 \sim 19$ & 55 & 28.5 \\
$20 \sim 29$ & 53 & 27.5 \\
$30 \sim 39$ & 22 & 11.4 \\
$40 \sim 49$ & 15 & 7.8 \\
$50 \sim 59$ & 10 & 5.2 \\
$60 \sim 69$ & 9 & 4.7 \\
$70 \sim$ & 1 & 0.5 \\
\hline 合 計 & 193 & 100.0 \\
\hline
\end{tabular}

表 3 1991 1995年に横浜市で起きたサルモネラ 食中毒事件の患者の症状の割合

\begin{tabular}{|c|c|c|c|}
\hline 症状 & 割合 (\%) & 症状 & 割合 (\%) \\
\hline 下 痢 & 94.8 & あい気 & 0.0 \\
\hline 発 熱 & 95.1 & 嘔 気 & 22.3 \\
\hline 嘔 吐 & 27.0 & 頭 痛 & 8.8 \\
\hline 腹 痛 & 43.3 & 悪 寒 & 13.0 \\
\hline \multirow[t]{2}{*}{ 臥 床 } & 51.2 & 戦 慄 & 2.7 \\
\hline & & 倦怠感 & 20.7 \\
\hline
\end{tabular}

※左列のデータのみ今回の推計に使用

※臥床の割合は入院患者以外のものである。
のの中での割合であり, さらに, 臥床の割合については, 入院患者を除いた割合を求妨ている。

\section{2 横浜市民全体を対象として発生を推定したサルモネ} ラ食中毒患者数の推計

Buzby ら ${ }^{31}$ は，CDCに報告される食中毒患者数が米国 内での食中毒患者数の実数よりもかなり少ないもである ことを考慮して cost-of-illness を推計している。

我が国においても食中毒統計に計上されたサルモネラ 食中毒の患者数が実際の患者数よりもかなり少ないであ ろうということが以前から指摘されている ${ }^{10111}$ 。しかし， 日本国内のサルモネラ症の発生患者数の推計については これまで行われていない。今回は，健康保菌者のデー夕 及びChalker ら ${ }^{6} の$ 推計法, 小野川ら ${ }^{12)}$ 調査結果などを 用いて図 1 のように横浜市民の中で 1 年間に発生するサ ルモネラ食中毒の患者数を推計した。推計の手順はまず すべてのサルモネラ症の患者数を推計した後にサルモネ ラ食中毒の患者数を推計している。

Chalker ら ${ }^{6)}$ は, 合衆国における年間のサルモネラの感 染者数は, 80 万人から 370 万人の間であると推計し，その 最大值である 370 万人という感染者数は, サルモネラの保 菌者数から次の式により推計を行っている。

$$
1 \text { 年間の感染者の発生率 }=\frac{\text { 保菌率 }}{\text { 排菌の期間 }(\text { 年換算 })}
$$

表 5 は福岡市衛生研究所 ${ }^{13)}$ 及び東京都予防医学協会 ${ }^{14)}$ による最近のサルモネラ菌の検出状況である，これらの デー夕は食品取扱者, 学校の宿泊行事の際の健康診断 (東 京), 保母 (福岡) などの検査結果から得られものであ る。この表からもサルモネラの保菌率は年毎, 地域ごと の差が見られる。横浜市が首都圈であることを考慮して， 東京都子防医学協会のデー夕を使用し横浜市のサルモネ ラ推定保菌率を0.042 0.103\%，また，排菌の期間は

表 4 サルモネラ菌の検出状況

\begin{tabular}{ccrrr}
\hline & \multicolumn{2}{c}{ 福岡市衛生研究所 $^{13)}$} & \multicolumn{2}{c}{ 東京都予防医学協会 ${ }^{14)}$} \\
\hline 年 & 検查件数 & 検出件数 $(\%)$ & 検査件数 & 検出件数 $(\%)$ \\
\hline 1989 & 38,312 & $5(0.013)$ & 247,698 & $242(0.098)$ \\
1990 & 38,494 & $14(0.036)$ & 221,755 & $203(0.092)$ \\
1991 & 39,929 & $9(0.023)$ & 213,113 & $219(0.103)$ \\
1992 & 40,785 & $30(0.074)$ & 205,185 & $205(0.100)$ \\
1993 & 42,745 & $40(0.094)$ & 105,008 & $49(0.047)$ \\
1994 & 44,242 & $39(0.088)$ & 71,546 & $30(0.042)$ \\
1995 & - & - & 72,023 & $31(0.043)$ \\
\hline
\end{tabular}

※福岡市衛生研究所のデー夕は年度単位のもの

※東京都予防医学協会の原版は割合を小数点以下 2 位で表記されている。 


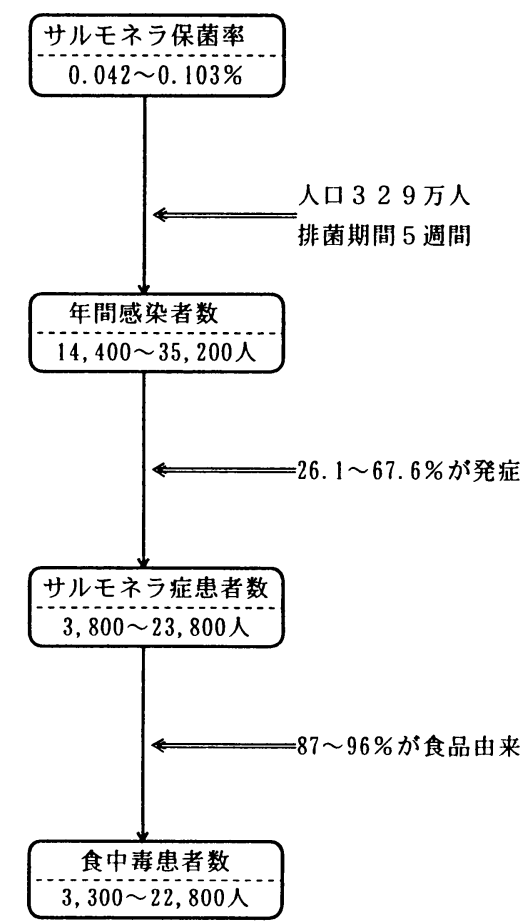

図 1 サルモネラ食中毒患者発生数の推計の流れ

\begin{tabular}{ccc} 
表 5 & \multicolumn{3}{c}{ 患者の自覚症状の割合 ${ }^{22}$} \\
\hline 症 & 状 & 割合 $(\%)$ \\
\hline 悪心 & 嘔吐 & 7.6 \\
腹 & 痛 & 68.8 \\
下 & 痢 & 86.8 \\
発 & 熱 & 17.4 \\
\hline
\end{tabular}

Chalker らと同様に Buchwald ら ${ }^{15)}$ の研究による 5 週間 （0.096年）という数值を使用した。この発生率に1993年の 横浜市の人口（約 329 万人）をかけて, 横浜市民の中の年 間のサルモネラ感染者数を 14,400 35,200人であると推 計した。

次にこの中から, 発症者の割合を推計した。野川ら ${ }^{121}$ は，1980年 1 月から1985年12月までの 5 年間に東京都子 防医学協会の検查でサルモネラが保菌された保菌者に対 し, 検査の前後 1 週間の自覚症状についてのアンケート 調査を行ったところ，2,272例のうち1，329例から回答が あり，そのうち545例 (44.5\%) が何らかの自覚症状を訴之 ていると報告している。小野川らの報告のうちの未回答 部分について，すべてが無症状例と仮定した数值を最低， すべてが発症していると仮定した場合の数值を最大とし て, 推定発症率を $26.1 \sim 67.6 \%$ とし, サルモネラ症患者 数を 3,800 〜 23,800 人と推計した。

最後にサルモネラ食中毒患者数の推計を行った。食中

\begin{tabular}{cc} 
表 6 & \multicolumn{2}{c}{ 患者の年齢階級別頻度 } \\
\hline 年歯 & 割合 $(\%)$ \\
\hline $0 \sim 4$ & 3.7 \\
$5 \sim 9$ & 13.0 \\
$10 \sim 14$ & 16.1 \\
$15 \sim 19$ & 5.8 \\
$20 \sim 29$ & 13.2 \\
$30 \sim 39$ & 11.4 \\
$40 \sim 49$ & 14.2 \\
$50 \sim 59$ & 12.1 \\
$60 \sim 69$ & 6.8 \\
$70 \sim$ & 3.7
\end{tabular}

毒以外のサルモネラ症の感染源としては日本でも, カメ からの感染事例 ${ }^{11)}$, 病院内での人から人への感染事例 ${ }^{16)}$, 健康保菌者のペットの所有数の報告 ${ }^{17)}$ な゙゙があるが，こ れらの感染者数が実際にどの程度の割合になるかという 推計は現在のところ行われていない。そこで, 米国の数 值ではあるが, Buzby らの用いたサルモネラ症患者にし めるサルモネラ食中毒患者の割合は87 96\%であるとい う数值を用いて，最終的に横浜市におけるサルモネラ食 中毒の患者数は3,300 22,800人であると推計した。

患者の自覚症状の割合は, 小野川ら ${ }^{12}$ の報告の割合 (表 6 ）を，また，患者の年齢構成は1991～1995年の食中毒 統計第11表9)の全国のサルモネラ食中毒事件の患者の年 齢階級別頻度を用いて計算したものを用いることとした。

\section{2 患者の受療パターンの推計}

患者の受㶗パターンは入院, 通院, 売薬を飲む, 何も しないの 4 つの区分に分けてそれぞれの患者数を推計し た。

横浜市のデータでは，入院患者は重症者として計上さ れているが，その他の患者の通院の有無については記載 されていない。また，日本国内の食中毒事件において患 者がどのような受療行動をとったかという調査も行われ ていない。そこで，サルモネラ食中毒の主な症状から， 下痢, 腹痛, 発熱, 嘔吐の症状の患者の割合に着目し, 平成 4 年度国民生活基礎調査 ${ }^{18)}$ のデー夕をもとに受療パ ターンの推計を試みることにした。

推計の方法は，まず, 症状のパターンごとの患者の割 合を推計し，次にそれぞれのパターン毎に治療行為の割 合を求め, 最後に症状のパターンごとの総患者数に対す る治療行為の割合を合計したものを最終的な受療パター ンの割合とした。

症:状のパターンごとの患者の割合は，横浜市のデータ，

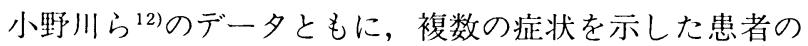
割合については記載されていない，そこで患者の症状に 


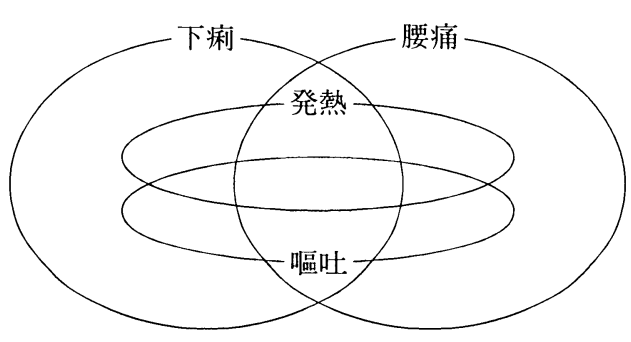

図 2 患者の症状パターンのモデル

ついて図 2 のようなモデルを考え，すべての患者が，下 痢もしくは腹痛の症状を示すとし，発熱及び嘔吐はどの 群の患者にも同じ割合で存在すると仮定して症状パ夕一 ンごとの患者の割合を推計した。

計算の方法は,

P D : 下痢の症状の患者の割合,

$\mathrm{P} \mathrm{V}$ : 嘔吐の症状の患者の割合,

P S : 腹痛の症状の患者の割合,

$\mathrm{PF}$ ：発熱の症状の患者の割合，とすると：

・下㾥のみの症状の患者の割合

$\mathrm{Pd}=(1-\mathrm{PS}) \cdot(1-\mathrm{PV}) \cdot(1-\mathrm{PF})$

・腹痛のみの症状の患者の割合

$\mathrm{Ps}=(1-\mathrm{PD}) \cdot(1-\mathrm{PV}) \cdot(1-\mathrm{PF})$

-下痢及び腹痛の症状の患者の割合

$\mathrm{Psd}=(\mathrm{PS}+\mathrm{PD}-1) \cdot(1-\mathrm{PV}) \cdot(1-\mathrm{PF})$

・下痢及び発熱の症状の患者の割合

$\mathrm{Pfd}=(1-\mathrm{PS}) \cdot(1-\mathrm{PV}) \cdot \mathrm{PF}$

・腹痛及び発熱の症状の患者の割合

$\mathrm{Pfs}=(1-\mathrm{PD}) \cdot(1-\mathrm{PV}) \cdot \mathrm{PF}$

-下痢, 腹痛及び発熱の症状の患者の割合

$\mathrm{Pfsd}=(\mathrm{PS}+\mathrm{PD}-1) \cdot(1-\mathrm{PV}) \cdot \mathrm{PF}$

-下痢及び嘔吐の症状の患者の割合

$\mathrm{Pvd}=(1-\mathrm{PS}) \cdot \mathrm{PV} \cdot(1-\mathrm{PF})$

・腹痛及び嘔吐の症状の患者の割合

$\mathrm{Pvs}=(1-\mathrm{PD}) \cdot \mathrm{PV} \cdot(1-\mathrm{PF})$

-下痢, 腹痛及び嘔吐の症状の患者の割合

$\mathrm{Pvsd}=(\mathrm{PS}+\mathrm{PD}-1) \cdot \mathrm{PV} \cdot(1-\mathrm{PF})$

-下痢, 発熱及び嘔吐の症状の患者の割合

$\mathrm{Pfvd}=(1-\mathrm{PS}) \cdot \mathrm{PV} \cdot \mathrm{PF}$

・腹痛, 発熱及び嘔吐の症状の患者の割合

$\mathrm{Pfvs}=(1-\mathrm{PD}) \cdot \mathrm{PV} \cdot \mathrm{PF}$

-下痢, 腹痛, 発熱及び嘔吐の症状の患者の割合 $\mathrm{Pfvsd}=(\mathrm{PS}+\mathrm{PD}-1) \cdot \mathrm{PV} \cdot \mathrm{PF}$

となる。

次に受療パターンの割合を推計した。平成 4 年度国民 生活基礎調查第 2 卷第29表18)には, 有訴者の主症状別の
表 7 有訴者の治療状況（\%)

\begin{tabular}{cccc}
\hline 主症状 & 通 院 & 売薬をのむ & 何もしない \\
\hline 下痢 & 36.4 & 30.6 & 33.0 \\
腹痛 & 52.2 & 27.1 & 20.7 \\
発熱 & 69.4 & 18.8 & 11.9 \\
嘔吐 & 48.8 & 18.7 & 32.5 \\
\hline
\end{tabular}

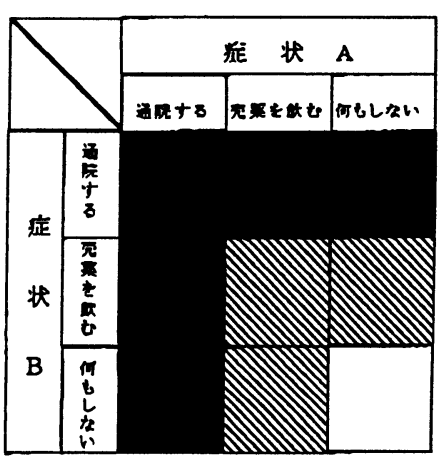

定状A及ひBがある旷に

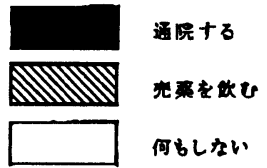

図 3 二症状をもつ患者の治療行動のモデル

表 8 1 人あたりの医療費の推計金額

（円）

\begin{tabular}{cccrccc}
\hline 診㙩行為 & 診察 & 投薬 & 注射 & \multicolumn{1}{c}{ 検查 } & 入院 & 合計 \\
\hline 入院 & 2,860 & 3,870 & 16,740 & 20,510 & 45,730 & 89,710 \\
通 院 & 3,060 & 2,420 & 580 & 1,160 & - & 7,220 \\
\hline
\end{tabular}

治療状況が記載されており, 主症状別に行った治療状況 が集計されている。このデー夕をもとに下痢, 腹痛, 発 熱, 嘔吐の主症状別の治療状況の割合を表 8 にまとめた。 なお, 嘔吐は, 吐き気・嘔吐として, 腹痛は腹痛・胃痛 として調査されているが, ここでは嘔吐, 腹痛と同じも のと考えることとした。また, 治療行動のうちの「通所 している」については通常のサルモネラ食中毒では, は ク，炎，マッサージは用いられないことから，「それ以外 の治療をしている」は数も少なく民間療法の実態が不明 であることから，それぞれを除いて割合を計算した。

各群ともに表 8 の割合で治療行動をとるものとし, 複 数の治療行動が重複する場合は,

通院している>売薬を飲む $>$ 何もしない

の順で行動が優先されると仮定して治療行動の割合を計 
算した。(二症状を示す場合は図 3 のようになる。)

計算方法は, 症状 $\mathrm{A}$ 単独のときの, 通院している, 売 薬を飲む，何もしないの割合がそれぞれ， $\mathrm{Ga}, \mathrm{Ma}, \mathrm{Na}$ と すると，

$$
\begin{aligned}
& 2 \text { つの症状 }(\mathrm{A} \text { 及び B }) \text { の患者の場合 } \\
& \mathrm{Gab}=1-\mathrm{Ga} \cdot \mathrm{Gb} \\
& \mathrm{Mab}=1-\mathrm{Gab}-\mathrm{Nab} \\
& \mathrm{Nab}=1-\mathrm{Na} \cdot \mathrm{Nb}
\end{aligned}
$$

3 つの症状 $(\mathrm{A}, \mathrm{B}$ 及び $\mathrm{C})$ の患者の場合

$\mathrm{Gabc}=1-\mathrm{Ga} \cdot \mathrm{Gb} \cdot \mathrm{Gc}$

$\mathrm{Mabc}=1-\mathrm{Gabc}-\mathrm{Nabc}$

$\mathrm{Nabc}=1-\mathrm{Na} \cdot \mathrm{Nb} \cdot \mathrm{Nc}$

4 つの症状 $(\mathrm{A}, \mathrm{B}, \mathrm{C}$ 及びD $)$ の患者の場合

$\mathrm{Gabcd}=1-\mathrm{Ga} \cdot \mathrm{Gb} \cdot \mathrm{Gc} \cdot \mathrm{Gd}$

Mabcd $=1-$ Gabcd - Nabcd

$\mathrm{Nabcd}=1-\mathrm{Na} \cdot \mathrm{Nb} \cdot \mathrm{Nc} \cdot \mathrm{Nd}$

となり，最終的な各治療行動の割合は,

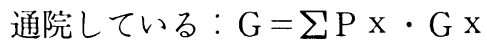

売菜を飲む $: M=\Sigma P x \cdot M x$
何もしない： $\mathrm{N}=\mathrm{P} \mathrm{P} \mathrm{x} \cdot \mathrm{N} \mathrm{x}$

となる。

この割合を総数にかけて受療パターンごとの患者数を 求妰図 4 , 図 5 )。横浜市民の中の推計患者数の入院患 者の割合は, 平成 5 年患者調査 ${ }^{19}$ の第 39 表推計受療傷病 数の腸管感染症の入院患者と外来患者の割合を用いて通 院しているの中から入院患者と通院のみの患者にわけた。

\section{3 患者 1 人あたりの医療費の推計}

サルモネラ症の治療は, 軽症例では, 安静と食飭療法 のみでよいが, 大量の水様下痢を呈する症例では, 輸液 を行う8)。また，抗菌剤の使用についてはニューキノロン 系製剤があるがその使用法についても様々な説があ

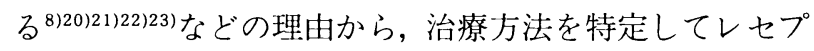
トの点数から医療費を推計することは困難である。そこ で, 今回は, 平成 5 年社会医療診療行為別調査報告 ${ }^{24)}$ の第 4 票の B1腸管感染症のデータから医療費の推計を試み た（表 9 )。使用したデー夕は入院及び入院外ともに「総 数」のデータを用いた。

入院患者の費用のうち, 診察, 投薬, 注射, 検査の項 目については 1 件あたりの平均金額を, 入院費について は 1 日あたりの平均入院費を算出し，それに推定入院日

何もしない (6人)

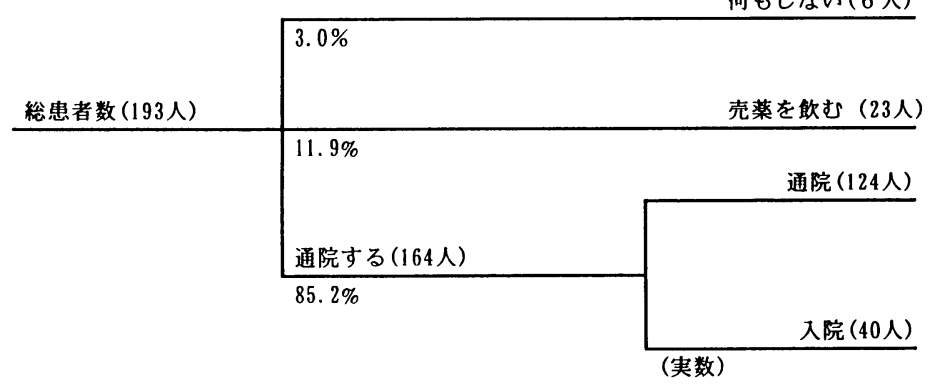

図 4 横浜市内でおきた食中毒事件（1991～1995年）の患者の推定受療パターン

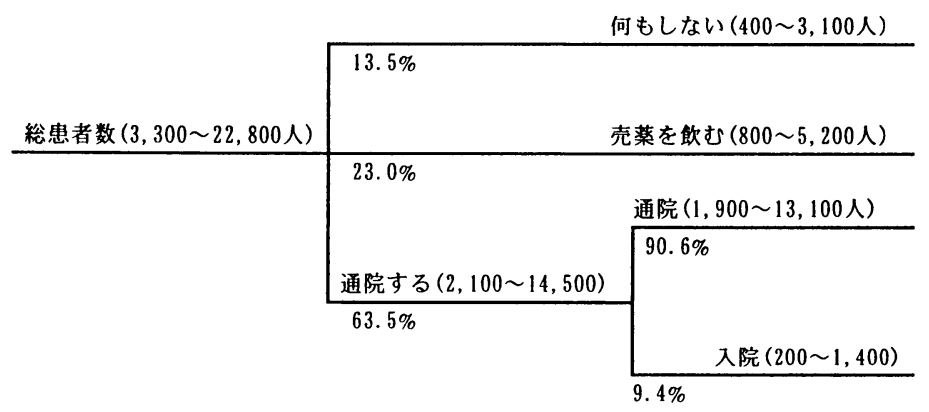

図 5 横浜市民全体を対象として発生を推定したサルモネラ食中毒患者の推定受療パターン 
数をかけたものとし，これらを合計することにより求め た。入院日数については, 深谷ら25)の研究に記載されて いる15人の患者の入院日数の中央值である 4 日とした。 通院患者の費用については, 診察, 投薬の項目につい ては 1 件あたりの平均金額を, 注射及び検査については, 総件数あたりの平均金額として求め, それらを合計する ことにより求めた。

売薬の值段は, 小売物価統計調査年報 ${ }^{26)}$ 第 1 表の県庁 所在地及び人口 15 万以上の市の胃腸薬（複合胃腸剂 $「 ハ ゚ ~$ ンシロン新胃腸薬（20包入り）」，顆粒状）の年平均価格 が733〜927円であること, 他の銘柄の売薬の可能性もあ ることから 1 人あたり1,000円とした。

\section{4 患者 1 人あたりの間接費用の推計}

間接費用は，サルモネラ食中毒により発生した所得損 失額として求めた。所得損失額は 15 才以上の患者は本人 のものを，0１4才までの患者は，母親が通院及び臥床期 間の世話をするものとして母親の所得損失額と仮定して 算出した。

推計方法は, 患者 1 人あたりの平均所得損失額をまず 推計し, 次に各受療パターン毎に患者の平均損失時間を 推計し，双方を掛け合わせることにより算出した。

4.1 患者 1 人・ 1 時間あたりの所得損失額の推計

所得損失額は，各年齢階級ごとの 1 時間あたりの平均 貢金に雇用率を掛け合わせたものとし，平均賃金は賃金 センサス27の第 1 巻第 1 表の産業計企業規模計全労働者 の年齢階級別の所定内給与額と所定内実労働時間を用い

表 9 子供の年齢階級に対する母親の年齢期待割合と平 均所得損失額

\begin{tabular}{|c|c|c|c|c|}
\hline \multirow[t]{2}{*}{ 母親の年歯 } & \multirow[t]{2}{*}{$\begin{array}{c}\text { 母親の } \\
\text { 所得損失額 }\end{array}$} & \multicolumn{3}{|c|}{$\begin{array}{c}\text { 子供の年齢階級に対する } \\
\text { 母親の年柃の期待割合 }\end{array}$} \\
\hline & & $0 \sim 4$ & $5 \sim 9$ & $10 \sim 14$ \\
\hline$\sim 17$ & 674 & 0.001 & & \\
\hline $18 \sim 19$ & 841 & 0.004 & 0.000 & \\
\hline $20 \sim 24$ & 1,010 & 0.084 & 0.004 & 0.000 \\
\hline $25 \sim 29$ & 1,177 & 0.338 & 0.084 & 0.003 \\
\hline $30 \sim 34$ & 1,277 & 0.399 & 0.374 & 0.081 \\
\hline $35 \sim 39$ & 1,269 & 0.144 & 0.387 & 0.427 \\
\hline $40 \sim 44$ & 1,256 & 0.029 & 0.135 & 0.401 \\
\hline $45 \sim 49$ & 1,242 & 0.001 & 0.015 & 0.075 \\
\hline $50 \sim 54$ & 1,219 & 0.000 & 0.001 & 0.013 \\
\hline $55 \sim 59$ & 1,171 & - & 0.000 & 0.001 \\
\hline $60 \sim 64$ & 1,093 & & 0.000 & \\
\hline $65 \sim$ & 1,089 & & 0.000 & \\
\hline \multicolumn{2}{|c|}{ 平均所得損失額 } & 1,217 & 1,261 & 1,263 \\
\hline
\end{tabular}

※所得損失類の単位は円 / 時間
て算出し, 雇用率は労働力調査年報28)の第14表より算出 した。

14才以下の所得損失額については,

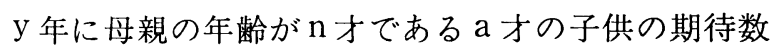
aPnを,

$\mathrm{aPn}=(\mathrm{y}-\mathrm{a})$ 年の母親の年龄 $(\mathrm{n}-\mathrm{a})$ 才の子供の出生数 $\times$ 生存率

と仮定して，各年龄階級ごとの母親の年齢階級の期待割 合を求め，それに母親の所得損失額をかけて年齢階級毎 に集計したものを所得損失額とした(表10)。データにつ いては人口動態統計 ${ }^{29}$ 第 6 表及び平成 5 年 10 月 1 日現在 推計人口 ${ }^{30}$ 第 4 表を用いた。なお，母親が尃業主婦である ことも考えられるが, 主婦の労働価值は，同年齢の女性 労働者の平均貢金と同程度という説年132)を支持し，母親 の機会損失額を賃金センサス第 1 表の産業計企業規模計 女子労働者学歴計のデー夕を用いて算出した。

このようにして算出された年㱓階級別の機会損失額に, 食中毒患者の年齢階級別頻度を掛け合わせて合計したも のを 1 人あたりの平均機会損失額とした（表11）。

4.2 各受療パターン毎の患者 1 人あたりの間接費の推計 損失時間については, 1 日の損失時間を 8 時間,半日の 場合は 4 時間とした, 通院時間については半日 (4 時間) とし, 通院回数は平成 5 年社会医療診療行為別調査報告 24)の第 4 票の入院外患者の診察件数と診察回数の比か ら平均1.8回とし, 1 回目と 2 回目の通院の間隔は平成 5

表10 年齢階級別の所得損失額と平均所得損失額

\begin{tabular}{lrrr}
\hline 年齢 & $\begin{array}{c}\text { 1時間あたりの } \\
\text { 所得損失額 }\end{array}$ & \multicolumn{2}{c}{ 患者発生数の割合 $(\%)$} \\
\cline { 3 - 4 } & 1,217 & 1.0 & 3.7 \\
$5 \sim 4$ & 1,261 & 4.1 & 13.0 \\
$10 \sim 14$ & 1,263 & 9.3 & 16.1 \\
$15 \sim 19$ & 861 & 28.5 & 5.8 \\
$20 \sim 29$ & 1,187 & 27.5 & 13.2 \\
$30 \sim 39$ & 1,708 & 11.4 & 11.4 \\
$40 \sim 49$ & 1,997 & 7.8 & 14.2 \\
$50 \sim 59$ & 1,974 & 5.2 & 12.1 \\
$60 \sim 69$ & 1,386 & 4.7 & 6.8 \\
$70 \sim$ & 1,314 & 0.5 & 3.7 \\
\hline 平均所得損失額 & & 1,278 & 1,479 \\
\hline
\end{tabular}

※所得損失額の単位は円/時間

※事件は, 1991 1995年に横浜市内でおきた食中毒事件の患者, 推計は横 浜市民全体を对象として発生を推定したサルモネラ食中毒患者をあら わす。 
年患者調査 ${ }^{199}$ の結果から約 6 日程度あくものとした。ま た，床についた平均日数については平成 4 年度国民生活 基礎調査18）第38表の急性腸炎及び下痢症の通院患者の 就床日数が 1 ～ 3 日であることから 2 日とした。

（1）横浜市内でおきた食中毒事件（1991～1995年）の患 者の場合

入院患者については 4 日間, 仕事に就けないものとし て32時間の損失とした。

通院患者については，臥床した $51.2 \%$ の患者は 2 日間 仕事に就けず，0.8回（1 回目は寝込んだ日数の中に計上 されている。)通院するものとして, 寝込んだ患者の損失 時間を 19 時間 $(8$ 時間 $\times 2$ 日 +4 時間 $\times 0.8$ 回 $)$, 寝込ま

表11 受療パターン・症状ごとの重症度の割合

\begin{tabular}{|c|c|c|c|c|}
\hline \multirow{2}{*}{$\begin{array}{l}\text { 受療 } \\
\text { パターン }\end{array}$} & \multirow[t]{2}{*}{ 症状 } & \multicolumn{3}{|c|}{ 重症度 (\%) } \\
\hline & & 寝込む & 少し寝込む & 寝込まない \\
\hline \multirow[t]{4}{*}{ 通院 } & 下痢 & 15.9 & 18.7 & 65.4 \\
\hline & 腹痛 & 11.1 & 20.9 & 68.0 \\
\hline & 発熱 & 40.2 & 34.6 & 25.2 \\
\hline & 嘔吐 & 25.9 & 35.5 & 39.5 \\
\hline \multirow[t]{4}{*}{ 売薬を飲む } & 下痢 & 7.9 & 6.7 & 85.4 \\
\hline & 腹痛 & 6.3 & 13.7 & 80.0 \\
\hline & 発熱 & 37.4 & 28.9 & 33.7 \\
\hline & 嘔吐 & 20.0 & 20.0 & 60.0 \\
\hline \multirow[t]{4}{*}{ 何もしない } & 下痢 & 3.2 & 4.2 & 92.6 \\
\hline & 腹痛 & 3.4 & 9.1 & 87.5 \\
\hline & 発熱 & 17.3 & 26.9 & 55.8 \\
\hline & 嘔吐 & 10.0 & 12.0 & 78.0 \\
\hline
\end{tabular}

ない患者の損失時間を 7 時間（ 4 時間 $\times 1.8$ 回）とした。 売薬を飲んだ及び何もしない患者については，寝込ん だ患者は 16 時間の損失，何もしない患者は損失時間なし とした。それぞれの受療パターンごとに平均損失時間を 計算し，それに平均機会損失額をかけて患者 1 人あたりの 間接費とした(表13)。

（2）横浜市民全体を対象として発生を推定したサルモネ 亏食中毒患者

表12は平成 4 年度国民生活基礎調査第 2 巻第 29 表 ${ }^{18)}$ の デー夕をもとに各受診行動別, 主症状別の重症度を計算 したものである。この值をもとに受療パターンの推計と 同様の方法で，各受療パターン毎の 1 日中床についた患 者，少し床についた患者，床につかなかった患者の数を 求めた。なお，入院患者は通院患者のうちの床についた 患者であると仮定して, 通院患者の重症度の割合を補正 した。

1 日中床についた患者は 2 日間就業できないものとし， 少し床についた患者は半日就業できないものと仮定した。 ただし，通院患者の少し床についたものは，通院に半日， 床についたのが半日の計 1 日就業できないものと仮定し た。

以上の様な仮定に基づき(1) と同様の方法で患者 1 人 あたりの間接費を推計した。（表15）

\section{5 総費用の推計}

総費用は各受療パターンの患者数に患者一人あたりの 医療費と間接費の推計額の和を掛け合わせて求めた。 その結果，表14及び16のとおり，1991～1995年に横浜

表12 横浜市内でおきた食中毒事件（1991～1995年）の患者の平均損失時間及び間接費用の推計值

\begin{tabular}{|c|c|c|c|c|}
\hline \multirow{2}{*}{$\begin{array}{l}\text { 受療 } \\
\text { パターン }\end{array}$} & \multicolumn{2}{|c|}{ 推定損失時間（症状の割合・\%） } & \multirow{2}{*}{ 平均損失時間 } & \multirow{2}{*}{ 間接費用 (円) } \\
\hline & 寝込む & 寝込まない & & \\
\hline 入院 & $32(100)$ & - & 32 & 40,900 \\
\hline 通院 & $19(51.2)$ & $7(48.8)$ & 13 & 16,600 \\
\hline 売薬を飲む & $16(51.2)$ & $0(48.8)$ & 8 & 10,200 \\
\hline 何もしない & $16(51.2)$ & $0(48.8)$ & 8 & 10,200 \\
\hline
\end{tabular}

表13 横浜市内でおきた食中毒事件（1991～1995年）の cost-of-illness

\begin{tabular}{|c|c|c|c|c|c|}
\hline & \multicolumn{3}{|c|}{ 1 人あたりの費用 (円) } & \multirow{2}{*}{ 患者数 (人) } & \multirow{2}{*}{ 費用 (円) } \\
\hline & 医療費 & 間接費用 & 合計 & & \\
\hline 入院 & 89,710 & 40,900 & 130,610 & 40 & $5,224,400$ \\
\hline 通院 & 7,220 & 16,600 & 23,820 & 124 & $2,953,680$ \\
\hline 売薬を飲む & 1,000 & 10,200 & 11,200 & 23 & 257,600 \\
\hline 何もしない & - & 10,200 & 10,200 & 6 & 61,200 \\
\hline 合計 & & & & 193 & $8,496,880$ \\
\hline
\end{tabular}

※金額はすべて1993年の円に換算している。 
表14 横浜市民全体を対象として発生を推定したサルモネラ食中毒患者の平均損失時間及び間接費用の推計值

\begin{tabular}{|c|c|c|c|c|c|}
\hline \multirow{2}{*}{ 受療パターン } & \multicolumn{3}{|c|}{ 推定撌失時間（重症度の割合・\%） } & \multirow{2}{*}{ 平均損失時間 } & \multirow{2}{*}{ 間接費用 (円 } \\
\hline & 1日中寝込む & 少し寝込む & 寝込まない & & \\
\hline 入院 & $32(100)$ & - & - & 32 & 47,300 \\
\hline 通院 & $19(23.6)$ & $11(32.4)$ & $7(44.0)$ & 11 & 16,300 \\
\hline 売薬を飲む & $16(14.1)$ & $4(15.3)$ & $0(70.6)$ & 3 & 4,400 \\
\hline 何もしない & $16(4.6)$ & $4(7.7)$ & $0(87.7)$ & 1 & 1,500 \\
\hline
\end{tabular}

表15＼cjkstart横浜市民全体を対象として発生を推定したサルモネラ食中毒の 1 年間の cost-of-illness

\begin{tabular}{|c|c|c|c|c|c|c|c|}
\hline & \multicolumn{3}{|c|}{1 人あたりの費用 $($ (円) } & \multicolumn{2}{|c|}{ 最小 } & \multicolumn{2}{|c|}{ 最大 } \\
\hline & 医療費 & 間接費用 & 合 計 & 患者数 (人) & 費用 (円） & 患者数 (人) & 費用 (円） \\
\hline 入院 & 89,710 & 47,300 & 133,610 & 200 & $27,402,000$ & 1,400 & $191,814,000$ \\
\hline 通院 & 7,220 & 16,300 & 23,520 & 1,900 & $44,688,000$ & 13,100 & $308,112,000$ \\
\hline 売薬 & 1,000 & 4,400 & 5,100 & 800 & $4,320,000$ & 5,200 & $28,080,000$ \\
\hline 何もしない & - & 1,500 & 1,500 & 400 & 600,000 & 3,100 & $4,650,000$ \\
\hline 合計 & & & & 3,300 & $77,010,000$ & 22,800 & $532,656,000$ \\
\hline
\end{tabular}

※金額はすべて1993年の円に換算している

市内でおきた食中毒事件の cost-of-illness はおよそ850 万円 (1993年の円に換算)（1 年あたり平均約 170 万円,患 者 1 人あたりの費用は約 44,000 円), 横浜市民全体を対象 として発生が推定されたサルモネラ食中毒の 1 年間の cost-of-illness はおよそ7,700万〜 5億3,000万円（患者 1 人あたりの費用は約 23,000 円）と推計された。

\section{考察}

1 cost-of-illness の推計方法について

今回の横浜市の食中毒の cost-of-illness の推計は, 既 存のデー夕を利用してできる限り正確な数值を計算する ようにつとめたが，いくつかの問題点をあげることがで きる。

まず，サルモネラ患者の発生数についての推計だが, 最初に考えなくてはならないのは保菌率のデータについ てである。小野川ら ${ }^{12)}$ は, 保菌例数の $44.5 \%$ が何らかの自 覚症状を訴えていること，激しい下痢と訴之た例数がそ のうちの $8.1 \%$ \%ったと報告しているが, 使用したデー夕 は食品取扱者などのいわゆる健康保菌者のデータである ため, 実際の保菌率はこれらのデータより高い可能性が

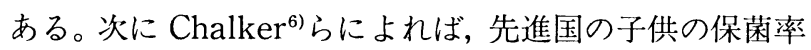
は大人の拉よそ 2 倍であると述べているが，今回使用し たデータは年齢の調整を行っていない。東京都予防医学 協会のデー夕は1992年を境に子供の割合が大きく変わる ため，このことを考慮に入れて保菌率を補正する必要が あったかもしれない。

次に排菌期間の問題である, Chalker ら ${ }^{6)}$ も Buchwald $ら^{15)}$ の求めた 5 週間という排菌期間についていくつかの
問題点をあげている。日本では, 発症者が 3 病週〜 3 ヶ 月, 健康保菌者が菌発見後 10 日 3 週で除菌されるとい う報告 ${ }^{23)}$ があるが, これは, 保菌者の除菌治療を行うこと を目的に書かれたデー夕なのでこれ以上期間を絞り込む ことは難しいと思われる。

小野川ら ${ }^{12)}$ の調査の結果もアンケート調査の結果であ るために, 本当にその症状がサルモネラによるものかと いう問題はあるが，小野川らは過去においても同様な調 査を実施し結果を発表しているが，だいたい似たような

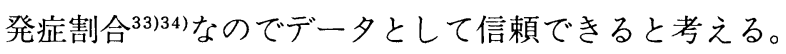
また, 検査日の前後 1 週間のみの調查であり, それ以外 の期間に症状が出た事例がある可能性も考えられるが, その問題は発症率に幅を持たせることで解消されたと考 える。

患者の受療パターンのモデルについては, 通院患者の 割合が多く出るようになっている。また, 医療システム が違うので単純に比較はできないが, Buzby ら ${ }^{3)}$ の推計 に比べても，全体に占める入院患者の割合が大きくなっ ておりこの点からも医療施設を利用する割合が現実より も多くなっているかもしれない。

医療費については，入院日数が 4 日では短かったので はないかということが考えられる。診療報酬調査を見る と, 腸管感染症の患者は平均 6 日程度入院しており, 患 者調查も腸管感染症の患者の入院日数の中央值はやはり 6 日である，また単純に比較はできないがアメリカの Cohen ら ${ }^{7}$ の調査では平均入院日数 6 日と報告されてお $\eta$, また, Blaser ${ }^{35)}$ の調查では入院日数の中央值が 7 日と報告されている。しかし, 国内のデータでは深谷ら 
のものしか確認することができなかった。同様に，患者 の就業不可能日数が, やはりアメリカの調査結果と比べ てかなり短くなっている。就業形態が違うので単純に比 較することができないがCohen らの調査では平均 12 日 間, Blaser ら $\left.{ }^{35}\right)$ の調査では中央值で 6 日間と報告されて おり，また，Levy ら ${ }^{36)}$ は，保健当局からサルモネラが㓌 性になるまでの間食品サービス業務につくことが禁止さ れた女性患者が結果として72日間職に就けなかった例を 報告している。日本ではこのような観点に立った疫学デ 一夕が無く, 経済損失の推計のためには今後このような 調査が必要になると考えられる。

\section{2 cost-of-illness の推計值について}

今回, 2 つの方法で求めた患者数についてのデー夕を 使用して cost-of-illness を推計した。

食中毒事件のデー夕を用いた推計では患者数が少なく, 受療パターンの推定人数の「何もしない。」が 6 人,「売 薬を飲む。が 23 人と少数である。しかしながら, 間接費 用の推計は，すべての患者の年齢割合を使用して行って いるために，実際に発生した個々の患者の間接費用の損 害額とは大きく異なると考えられる。患者数が少ない場 合の cost-of-illness の推計に今回のような手法は適当 でないのかもしれない。横浜市民全体を対象として発生 を推定した場合については，個々の患者の具体的な状態 がわからないので平均所得損失額を推計するという手法 を用いることしかできないが，事件数のデー夕を用いる 場合は個々の患者を把握できる状態にあるので，これら

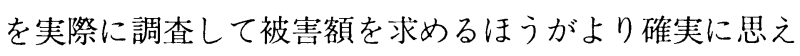
る。しかし, 今回の推計に際して把握できたアメリカに おける個々のサルモネラ食中毒の経済的損失についての 報告はわずかに 3 例のみ(735)36)であり，また，Buzby ら² がカンピロバクターの cost-of-illness の推計の際に使 用している 1 人あたりの費用のデー夕は Cohen ら》のサ ルモネラ食中毒についての調査データである。このよう に, アメリカにおいても個々の食中毒事件の被害額の調 查が容易ではないことが推測され，日本においてもこの ことは同様である考えられる。得られる結果の妥当性と 結果を得るための労力のバランスをどのようにとってい くかが今後の cost-of-illness 推計の1つの課題である と考えられる。

横浜市内で起きた食中毒事件の患者は，必ずしも横浜 市民に限らないこと，横浜市民が市外の施設で食中毒に 感染することもあり得ることから，この 2 つの数字を単 純に比較することは不適切であるかもしれないが，今回 用いた手法では, 患者 1 人あたりの平均費用は食中毒事 件のデータからの推計の方が横浜市民全体を対象として
発生を推定したサルモネラ食中毒の推計よりも約 2 倍大 きいにもかかわらず，総費用は逆に横浜市民全体を対象 として発生を推定したサルモネラ食中毒の費用の方が食 中毒事件の費用を大きく上回っている。このことから食 中毒事件ではサルモネラ食中毒の患者のうち比較的症状 の重い者が把握されているが，それ以外に事件とならな い比較的症状の軽い患者が多数存在し実際に把握されて いるよりもかなり大きい被害が生じている可能性がある と考之られる。実際に発生する被害を正確に把握するこ とは, 経済損失の推計の基礎であり, 食中毒患者の発生 状況はその最も重要な要素である。米国では CDCに報 告された食中毒患者数と実際の患者数との違いを推定し, これを修正するための研究が行われている ${ }^{316}$ が日本で はこのような研究はほとんど行われていない。辺野ら ${ }^{10)}$ は, サルモネラ食中毒だけでなく, 腸炎ビブリオ, 黄色 ブドウ球菌による食中毒についても，食中毒統計の数字 以上の患者が存在する可能性があることを指摘しており， 今後, 日本においても食中毒患者の数をより正確に推計 する研究の必要が大いにあると考える。

\section{3 損害賠償金額からの経済損失の推計について}

食中毒事件の患者数から推計した cost-of-illness の 1 年あたりの金額はおよそ170万円であり，また，静岡県 の調査 ${ }^{4}$ では食中毒の医療費・見舞金・慰謝料は総額（休 業にともなう費用, 食品の破妄費用, 雑費を加えたもの) の $16 \%$ に及ぶと報告されている。仮にこの費用の 2 分の 1 が医療費と慰謝料の一部（休業補償金）だと仮定する と 1 年間の被害総額は約 2,100 万円になる。単純に比較す ることはできないが，この額は横浜市民全体を対象とし て発生を推定したサルモネラ食中毒の cost-of-illness の最小推計額の 3 分の 1 にすぎない。損害賠償金は事件 や事故にしか支払われないため，損害賠償金の額をすべ て加算したとしても，現実の損失にはるかに及ばない可 能性がある。ただし，損害賠償金額のデー夕が，現実の 1 人あたりの医療費や生産性損失を推計する上では重要 なデータとなる可能性は十分あると考えられる。

\section{4 今後必要となる疫学調查について}

現在のところ, 経済的損失を把握するためには, 今回 行った cost-of-illness の推計のように, いくつかの既存 の疫学調查のデータを組み合わせて全体を把握していく 手法を用いることがより扱いやすく現実的であると考ら れる。

従来の食中毒の疫学調查は食中毒事件の原因を究明し, 搪大と再発を防止することを目的とするものがほとんど であった。しかし, 今回サルモネラ食中毒の cost-of-ill- 
ness 推計を試みることにより，より精度の高い cost-ofillness の推計を行うためには, 食中毒についての次のよ うな疫学調査が必要であると考えられる。

（1）食中毒患者の発生数の実態を把握する方法について の研究

これは cost-of-illness の推計に限らず，食中毒に対す る対策を立てる場合や，対策の効果を測定するために必 要となるものである。また，発生数は原因となる細菌が 食中毒を発生させるリスクをあらわす数值であるので, この方法は, 結果が可能な限り即時性をもってリスクの 変化に連動すること, 地域単位で取得可能なデー夕を使 用できることの $2 つ の$ 要件を備えていることが望ましい と考えられる。

（2）食中毒患者の発生数の実態を把握するために必要な 基礎的データの調査

今回サルモネラ食中毒の患者数の推計に用いた手法を 例にとると, 保菌率の実態の推計, 平均排菌期間の推定, 発病者率の推計, 全てのサルモネラ症患者にしめる食中 毒患者の割合の推計などである

（3）食中毒患者の経済損失を調査するために必要な基礎 データの調査

これは, 患者の重症度と医療行動，それに対する損害 の実態調查である。デー夕の形式はCohen らの調査のよ うに将来の物価や貢金の変動に耐えうるものが望ましい と考えられる。

\section{要 約}

食中毒による被害はこれまで事件数, 患者数, 死者数 という直接的な被害を表す数值によって表現されてきた。 しかし，このような指標は原因の異なる食中毒の被害を 十分に比較できず，食中毒が社会的又は経済的に及ぼす 影響について評価し難いという問題を持っている。

細菌性食中毒による経済損失の推計方法及び推計に 必要なデー夕を調べるために米国農務省の Buzby らが 行った cost-of-illness の推計方法を検討した。

その結果, 現在の日本では Buzby らが使用したもの と同様な疫学データがないために同じ方法で推計を行う ことができないことが判明した。そのため，現在入手可 能なデー夕を使用して横浜市におけるサルモネラ食中毒 の cost-of-illness の推計を行なった結果，1991～1995年 に横浜市内でおきた食中毒事件の cost-of-illness はお よそ850万円 (1993年の円に換算）（1 年あたり平均約 170 万円，患者 1 人あたりの費用は約 44,000 円)，横浜市民の なかで発生したサルモネラ食中毒の 1 年間の cost-ofillness はおよそ7,700万〜 億 3,000 万円）（患者 1 人あた

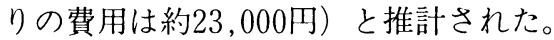

今後, 精度の高い cost-of-illness の推計を行うために は，使用する質の高いデータを得るための疫学研究の充 実が必要であると考えられる。

\section{謝辞}

今回の研究は, 平成 9 年度厚生科学研究特別研究およ び伊藤記念財団により助成された。

本研究を行うにあたり，貴重なデー夕を提供いただい た横浜市衛生局食品衛生課の皆様に厚くお礼を申し上げ ます。

\section{文献}

1 ）厚生省生活衛生局食品保健課監視係, 平成 8 年度食 中毒発生状況，食品衛生研究，1997；47 (9)：66-94

2 ) 小澤義博,経済疫学の重要性, 獣医情報科学雑誌, 1996; 37: 13-16

3 ) Jean C. Buzby, Tanya Roberts, C.-T. Jordan Lin et al. Bacterial Foodborne Disease:Medical Cost and Productivity Losses. Washington,DC : U.S. Department of Agriculture 1986

4) 静岡県保健衛生部, 平成 8 年静岡県の食中毒, 静岡, 1997: 10-11

5 ) 小川京子, 藤野志朗, わが国における骨粗鬆症の Cost-of-illness の推計（1992年度）, 医療と社会, 1996; 6 (2): 1-15

6 ) Richard B. Chalker, Martin J. Blaster, A review of human salmonellosis:III. Magnitude of salmonella infection in the United States. Reviews of Infectious Diseases, 1988; 10(1): 111-124

7 ) Mitshell L. Cohen, Robert E.Fontaine, Robert A. Pollard et al. An assesumennt of patient-rerated economic costs in an outbreak of salmonellosis. The New England Journal of Medicine, 1978; 299: 459-460

8 ）村田三紗子, 細菌性食中毒 サルモネラ, 齋藤誠, 中 谷林太郎，橋本博，他編，腸管感染症，東京，医典 社, 1984: 232-243

9 ）厚生省大臣官房統計情報部，厚生省生活衛生局食品 保健課, 平成 $3 \sim 7$ 年食中毒統計, 厚生省大臣官房 統計情報部，東京，1992-1997

10）辺野喜正夫，坂井千三，わが国のおもな細菌性食中 毒の動向, 日本公衆衛生誌, 1976; 23 (7): 258-267

11）善盖寺浩, サルモネラ症, 感染症学䧱誌, 1978; 52 (3): 95-97

12）小野川尊, 天野祐次, 市瀬正之他, 健康保菌者検索 
により発見されたサルモネラ陽性者の健康状態アン ケート調査成績, 予防医学ジャーナル, 1985; 198: 30 $-38$

13）塩津幸恵, 福岡市における健康人からのサルモネラ 検出状況 (1985-1994), 日本公衆衛生誌, 1996, 43 (2): 136-141

14）東京都予防医学協会, 平成 7 年度細菌検査の実施概 況, 東京都子防医学協会, 東京都予防医学協会年報, 東京, 26: 228

15) Dedra S. Buchwald, Martin J. Blaser, A reviw of human salmonellosis: II. Duration of exceretion following infection with nontyphi Salmonella. Reviews of Infectious Diseases, 1984; 6(3): 345356

16）西村忠史, 田吹和雄, 高島俊夫他, 病院内で発生し たサルモネラ下痢症んいついて一臨床的ならびに疫 学的検討一, 感染症学雑誌, 1982; 56 (6): 486-494

17）小野川尊, 天野祐次, サルモネラ健康保菌者とペッ 卜用カメ飼育との関係に関する調査, 日本公衆衛生 誌，1988; $35(3):$ 146-150

18）厚生省大臣官房統計情報部，平成 4 年国民生活基礎 調查第 2 巻全国編，東京，1994

19）厚生省大臣官房統情報部, 平成 5 年患者調查（下 巻), 東京, 1995

20）相楽裕子, 細菌感染症 (サルモネラ症), 島田馨, 朝 倉均, 太田保世, 他編, 内科学書第 1 巻, 東京, 中 山書店, 1995: 903-905

21）小野川尊，天野祐次，市瀬正之他，サルモネラ保菌 者の現状と管理, 予防医学ジャーナル, 1982; 166: 8 $-17$

22）東京都感染症マニュアル検討委員会, 東京都感染症 マニュアル，東京都政策報道室都民の声情報公開課， 東京, 1996: 96-97, 172-173

23）斉藤誠，村田美紗子，サルモネラ症，馬場一雄，小 林登，小児の下痢症〈小児科 MOOK No10.), 東京,
1980: $95-101$

24）厚生省大臣官房統計情報部，平成 5 年社会医療診療 行為別調査報告上巻, 東京, 1995

25）梁谷一太，友利玄一，庄司紘史，サルモネラ感染症 にかんする臨床的観察，日本伝染病学会雑誌，1969; $44(6): 91-98$

26）総務庁統計局, 小売物価統計調査年報 平成 5 年, 日本統計協会, 東京：1994

27）労働省政策調査部編，貢金センサス（平成 6 年度版） 平成 5 年賃金構造基本統計調査第 1 巻，労働法令協 会, 東京, 1994

28）総務庁統計局, 労働力調查年報平成 5 年, 東京, 1994

29）厚生大臣官房統計情報部, 昭和54年 平成 5 年人口 動態統計, 東京, 1979-1993

30）総務庁統計局, 平成 5 年 10 月 1 日現在推計人口, 東 京, 1994

31）前田信雄, 保健の経済学, 東京大学出版会, 東京, 1979:25-44

32）塩崎勤，貢金センサス利用上の諸問題，判例タイム ズ, 1997; 943: 76-82

33）小野川尊, 寺山武, 坂井千三，健康保菌者検索によ るサルモネラ保菌の実態についてー主として小中学 生を対象とした場合一, 日本伝染病学会雑誌, 1969; $43(9): 225-231$

34）小野川尊, 天野祐次, 寺山武, 健康保菌者検索によ るサルモネラ保菌の実態について 第 2 報 保菌率の 年次別推移と保菌者の症状の有無, 感染症学雑誌, 1972; 46 (2): 52-58

35) Martin J. Blaster, Earle M. Rafuse, Joy G. Wells et al. An outobreak of salmonellosis involving multiple vehicles.American Journal of Epidemiology, 1981; 114: 663-670

36) Barry S. Levy, Ward Mclntire, The economic inpact of a food-bone Salmonellosis outbreak. JAMA, 1974; 230: 1281-1282 